\title{
A gênese do discípulo. Uma relação semântica e teológica de Paulo e João a partir do estudo de FI 3,1-16 e Jo 15,1-8
}

\author{
Orientador: Geraldo Dondici Vieira
}

Doutorando: José Otácio Oliveira Guedes

Área de Concentração: Teologia Bíblica

Linha de Pesquisa: Análise e Interpretação de Textos do Antigo e Novo Testamento

A gênese do discípulo. Uma relação semântica e teológica de Paulo e João a partir do estudo de Fl 3,1-16 e Jo 15,1-8. Com a atenção voltada à unidade de toda a Escritura e ao horizonte da fé da Igreja, destinatária e guardiã da Revelação, este pesquisa estabeleceu uma relação de textos de corpora distintos, superando, assim, o marco rígido estabelecido por Bultmann. Fazendo a exegese das perícopes paulina de F1 3,1-16 e joanina de Jo 15,1-8, foi constatada em cada perícope densa concentração cristológica, diretamente ligada ao início do discipulado. Aproximando o resultado do estudo dos dois textos foi verificada a existência de uma gramática comum entre Paulo e João, tendo como marcos a semântica e a teologia no que tange ao essencial para se tornar discípulo. Essa gramática comum é accessível ao ouvinte-leitor de todos os tempos. Por isso, o estudo foi feito com atenção ao método histórico crítico, mas complementando-o com novos métodos de análise sincrônica, particularmente a análise narrativa, para revelar a contribuição dos textos enquanto esses são regra para a vida da comunidade de fé que hoje escuta e lê estes textos. Conclui-se que Paulo e João têm um testemunho comum sobre o essencial do vir a ser e da existência do discípulo; essa novidade diz respeito à ontologia do discípulo: estar compenetrado no ser de Jesus Cristo; para dizer com Paulo, o discípulo precisa "ser encontrado nEle"; para fazer eco do evangelho de João, diz-se: "permanecei em mim".

Palavras-chave: discipulado, ouvinte-leitor, análise narrativa. 